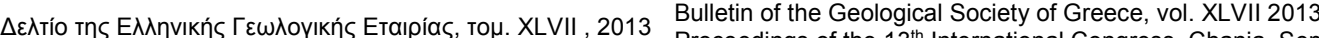
Proceedings of the $13^{\text {th }}$ International Congress, Chania, Sept.

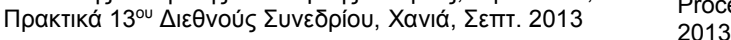

\title{
EARLY-MIDDLE MIOCENE FROM KOTAPHI HILL SECTION (NICOSIA, CYPRUS): PRELIMINARY BIOSTRATIGRAPHY AND PALEOCEANOGRAPHIC IMPLICATIONS
}

\author{
Athanasiou M. ${ }^{1}$, Triantaphyllou M. ${ }^{1}$, Dimiza M. ${ }^{1}$, Gogou A. ${ }^{2}$, Bouloubassi I. ${ }^{3}$, \\ Tsiolakis E. ${ }^{4}$ and Theodorou G. ${ }^{1}$ \\ ${ }^{I}$ National and Kapodistrian University of Athens, Faculty of Geology and Geoenvironment, \\ athanasioum@geol.uoa.gr \\ ${ }^{2}$ Hellenic Centre for Marine Research, Institute of Oceanography, 19013 Anavyssos, Attiki \\ ${ }^{3}$ Laboratoire d'Océanographie et du Climat, Expérimentation et Approche Numérique, Université \\ Pierre et Marie Curie, Paris Cedex 05, France \\ ${ }^{4}$ Geological Survey Department of Cyprus, 1 Lefkonos Street, 2064 Strovolos Lefkosia Cyprus
}

\begin{abstract}
Calcareous nannofossil biostratigraphy from Kotaphi Hill section allowed not only the biostratigraphic zonation of the Miocene units but also provided evidence for a distinct warm phase known as the Middle Miocene Climate Optimum (MMCO). Kotaphi Hill section is located in Agrokipia village (Nicosia region, Cyprus) and consists of cyclic marine deposits of the Pakhna Formation. High resolution sampling has been conducted and 84 samples were collected. Preliminary results indicated that several important calcareous nannofossil events can be consistently recognized along the studied section. High abundances of Discoaster druggii and Highest occurrence (HO) of Sphenolithus procerus suggest the presence of NN2 biozone while, LO of Sphenolithus belemnos has been used to recognize the base of biozone NN3. Upwards, Lowest Common Occurrence (LCO) of Sphenolithus heteromorphus marked the NN3-4 boundary-level. Biozone NN4 in Kotaphi Hill section is featured by high abundance of $S$. heteromorphus whereas total absence of the species together with the LO of Helicosphaera walbedorfensis mark the Paracme Beginning $(P B)$ of $S$. heteromorphus interval. High abundance of warm indicators such as Discoasterids, S. heteromorphus, S. moriformis and Helicosphaera carteri observed in our material may partly reflect the warm phase of MMCO.

Key words: Agrokipia village, Pakhna Formation, Cyprus, Sphenolithus heteromorphus, Middle Miocene Climate Optimum.
\end{abstract}

\section{Пєрі́ $\eta \psi \eta$}

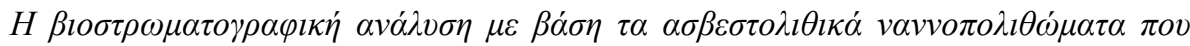

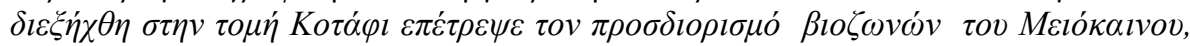

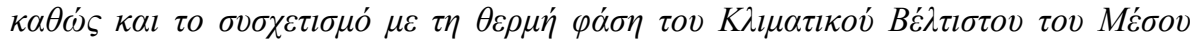

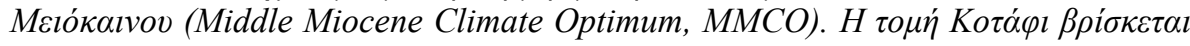

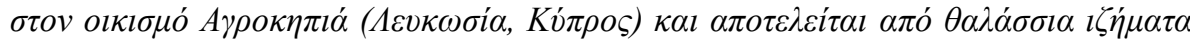

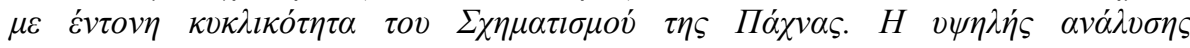

$\underline{\text { XLVII, No } 1 \text { - } 62}$ 


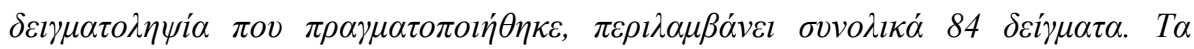

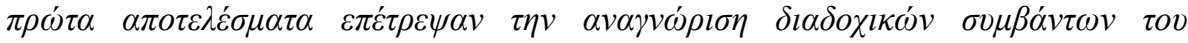

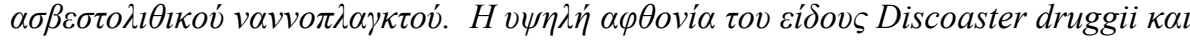

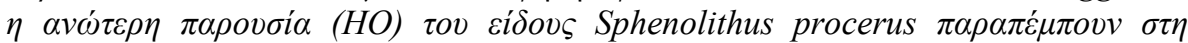

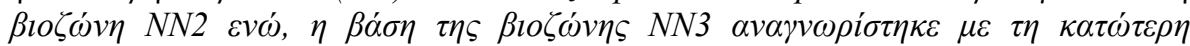

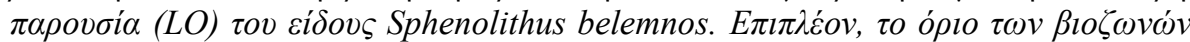

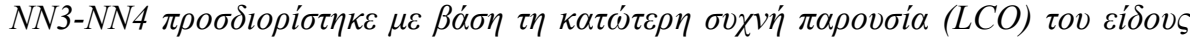

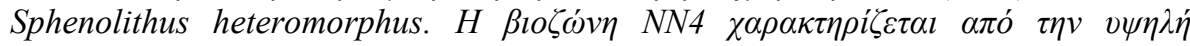

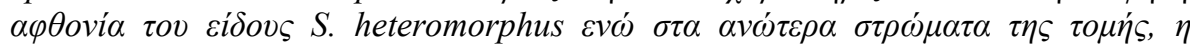

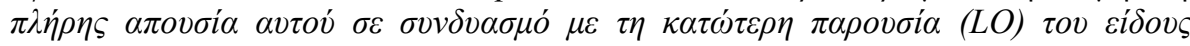

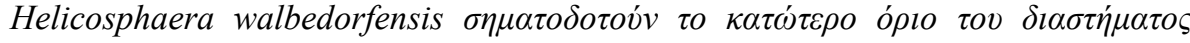

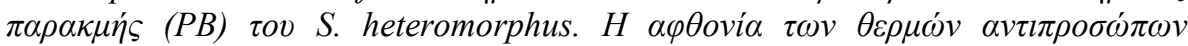
Discoasterids, S. heteromorphus, S. moriformis kal Helicosphaera carteri $\pi$ ov

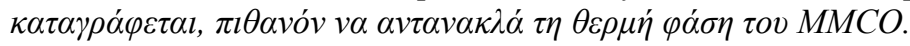

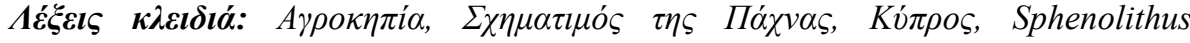

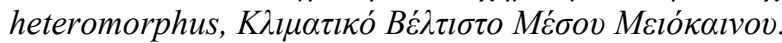

\section{Introduction}

The continuing collision of the European and African plates resulted to the final closure of the Tethys Ocean and the birth of the Mediterranean Sea. The last vestiges of the Mesozoic Tethys oceanic crust are today represented by the ophiolitic chain of the Troodos Massif, located on the hanging wall of the Cyprus subduction zone (Robinson \& Malpas, 1990). Geologically, Cyprus can be generally divided into five main geological terranes (1) Troodos Ophiolite Complex, (2) Mamonia Terrane, (3) Keryneia Terrane, (4) Circum-Troodos Sedimentary Succession and (5) Quaternary units. Ophiolite genesis started at Late Cretaceous and formed the Troodos Ophiolite Complex (TOC) which was obducted much later in the Middle Miocene. The subsequent period of low tectonic activity was dominated by deposition of carbonate rich sediments, commencing with the deep marine Lefkara Formation. However, an abrupt change to more localised, tectonically controlled deposition took place in the Early Miocene, initiating deposition of the Pakhna Formation. This phase was then followed by the formation of numerous shallow depositional basins containing gypsiferous sub-units of the Messinian salinity crisis that occurred when the Mediterranean was closed and sea levels dropped (Rouchy et al., 2001). Salinity crisis was followed by an abrupt uplift of the area that occurred during the Pleistocene at $\sim 2 \mathrm{Ma}$, resulting to the deposition of Pleistocene fanglomerates, mainly on the northern flanks of the Troodos Massif.

Middle Miocene is not only considered as crucial time interval for the evolution of the Earth climatic system, but also for the dynamic geologic evolution of the Mediterranean region. Such important geodynamic and paleoclimatic issues need a well-established biogeochronologic framework. Calcareous nannofossil have been proven extremely useful for the biostratigraphy of marine sediments, providing essential time-constrain for regional and worldwide biostratigraphic correlations. (e.g., Perch-Nielsen, 1985).

Aim of the present study is to test the reliability of Early to Middle Miocene calcareous nannofossil biohorizons at the Kotaphi Hill section (Cyprus Island), in order to improve the time resolution in the region and to provide paleoceanographic implications during the Middle Miocene Climate Optimum (MMCO) in south-eastern Mediterranean.

\section{Materials and Methods}

\subsection{Study Area}

Kotaphi Hill section $\left(05^{\circ} 13^{\prime}\right.$ E, $38^{\circ} 78^{\prime} \mathrm{N}$ ) is located in Agrokipia village (Nicosia region, Figure 1). It consists of well-preserved cyclic marine sediments of Pakhna Formation, which includes a 
range of shallow-to deeper-water carbonates and subordinate terrigenous sediments that were mainly deposited by pelagic and gravity-controlled processes. Pakhna Formation is overlain by the evaporitic Kalavasos Formation (Follows \& Robertson, 1990), which are similar to the Messinian evaporites elsewhere in the Mediterranean (e.g., Hsü, 1973), and is underlain by complete successions of Late Cretaceous-Oligocene deep-water pelagic limestones and calciturbidites of the Lefkara Formation (Robertson, 1976). Although the base of the Pakhna Formation appears to be of Aquitanian age in northern and southeastern Cyprus, (Robertson et al., 1991) limited data from southern Cyprus indicate ages ranging from Burdigalian to Langhian, implying the diachronous base of the formation. Two members are recognized within the Pakhna Formation: the Early Miocene Terra Member and the Late Miocene Koronia Member. The first phase, of Terra Member (Aquitanian-Burdigalian), is exposed only in SE and $\mathrm{W}$ of Cyprus while the latter, Koronia Member (Tortonian), is exposed, both fringing the Troodos Massif in north, south and west Cyprus, and on the Akamas Peninsula of NW Cyprus (Follows \& Robertson, 1990). Both phases of Pakhna Formation witness progressive changes through the Miocene that resulted from a combination of local Cyprus tectono-stratigraphic effects, general Mediterranean features and global climatic control.

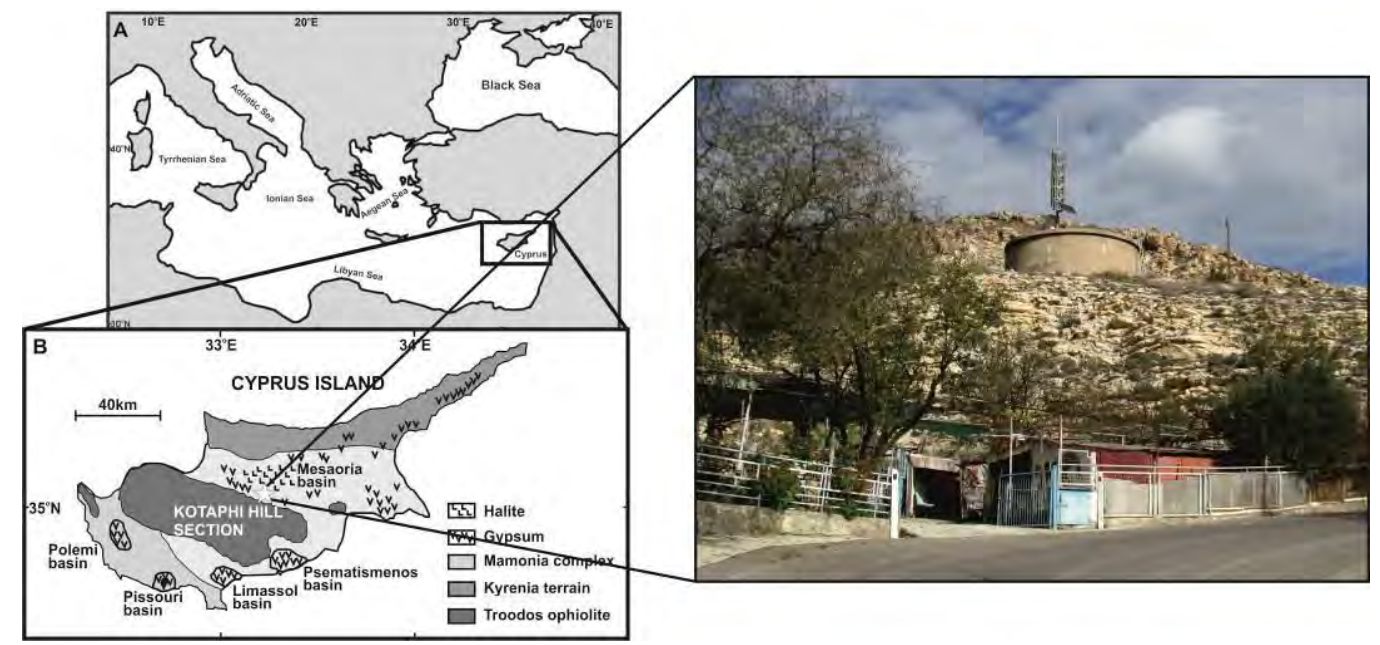

Figure 1 - Geologic sketch map of Cyprus Island. The location of Kotaphi Hill section is marked.

Our data cover mainly the Early Miocene deposits, outcropping in Kotaphi Hill section. Our first results refer to the lower part the section (Figure 2), with total height of $16.50 \mathrm{~m}$. The lower $1.5 \mathrm{~m}$ consists of marly chalk layers, which are passing to $7 \mathrm{~m}$ of laminated chalky layers, alternating with chalky marl layers. The following $10.5-13.5 \mathrm{~m}$ of the section is characterized by chalky layers alternating with marls and marly chalks. Sediments of the uppermost $3 \mathrm{~m}(13.5-16.50 \mathrm{~m})$ are featured by laminated alternations between chalk and chalky marls. High resolution sampling of the section has been conducted with an average sampling resolution of $20-30 \mathrm{~cm}$. A total number of 84 samples were collected and 25 samples from different levels of the section have been used for the purpose of this study.

\subsection{Calcareous Nannofossil Analysis}

For calcareous nannofossil analysis the preparation of samples followed the standard smear slide technique described by Perch Nielsen (1985). All sediment samples were routinely examined under a light microscope at a magnification of $1250 \mathrm{x}$, carried out using a Leica DMSP polarising light microscope (Dept. of Hist. Geology and Paleontology). In order to obtain accurate biostratigraphic estimations, up to 100 fields of view have been investigated per slide. Calcareous 


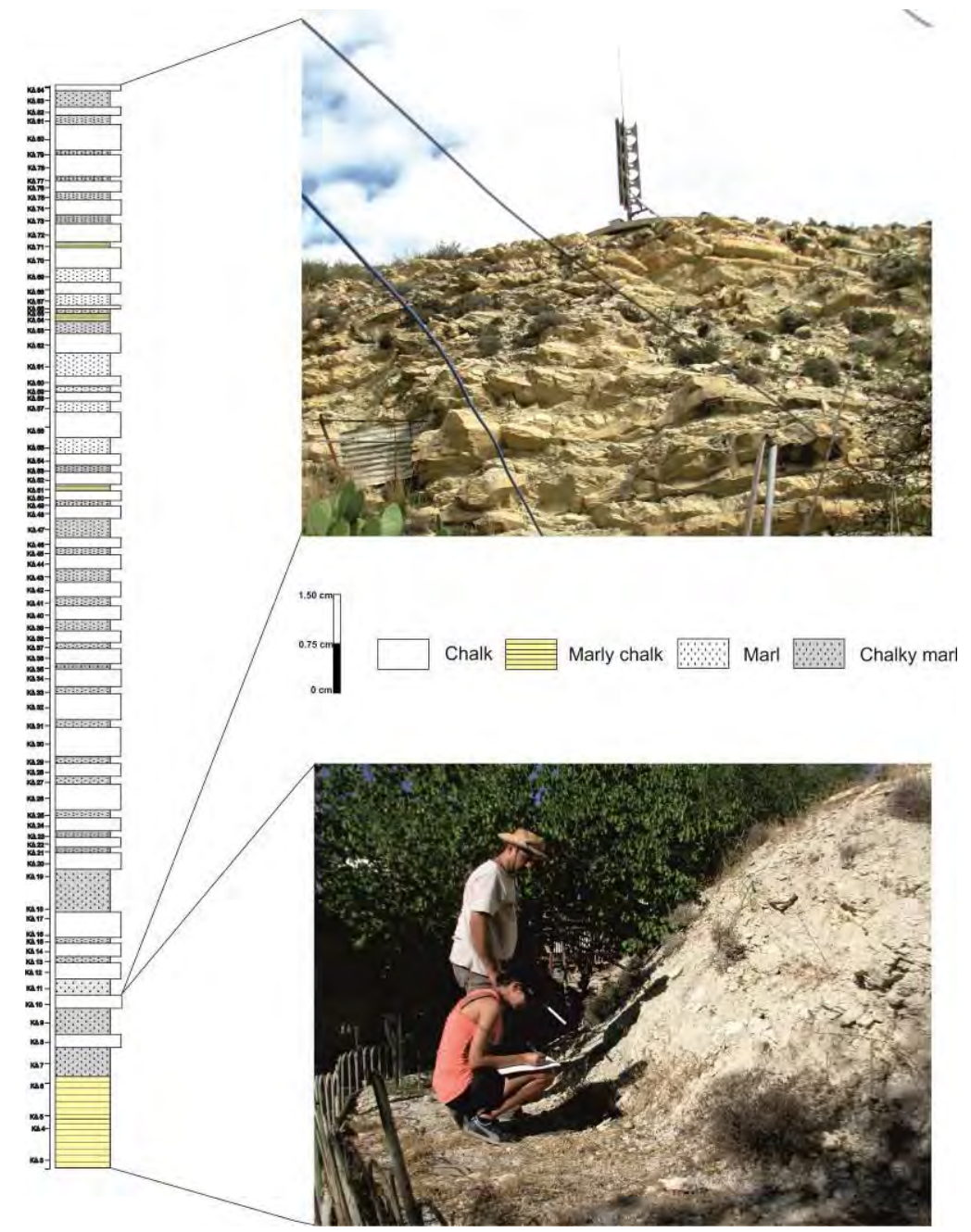

Figure 2 - Detailed lithostratigraphy of Kotaphi Hill section and sample location.

nannofossil biostratigraphy, mainly based on the appearance/disappearance and relative abundance patterns of selected species, provided high time resolution and accurate correlation with regional and global stratigraphy and time scales for the Miocene marine successions (e.g., Fornaciari et al., 1996; Fornaciari \& Rio, 1996; Lourens et al., 2004; Raffi et al., 2003; 2006, Hüsing et al., 2010). Lowest (LO) and highest (HO) occurrence of the index species, concern their first and last occurrence respectively, whereas LCO (Lowest Consistent Occurrence) and HCO (Highest Consistent Occurrence) indicate biohorizons which mark the beginning and end, respectively, of the consistent (continuous and/or common) distribution of index species. A LCO biohorizon thus represents an increase in abundance above the first appearance of the taxon, while an HCO biohorizon corresponds to a consistent drop in abundance prior to the extinction. Furthermore, PB (Paracme Beginning) and PE (Paracme End) indicate biohorizons which mark the beginning and end, respectively, of an interval in which the index taxon is temporarily absent, or present with scattered single specimens (Paracme interval).

Abundances of the taxa encountered in this paper were recorded as follows: A, abundant: more than one specimen every field of view; $C$, common: 1 specimen/10 fields of view; $R$, rare: 1 specimen/ 50 fields of view; $\mathrm{P}$, present: 1 specimen/ $>100$ fields of view; RW, reworked specimens. The taxonomy of the determined calcareous nannofossil species has been based on

$\underline{\text { XLVII, No } 1-65}$ 
Aubry (1984-1999) and Perch-Nielsen (1985). The determination of the biostratigraphic events has followed Martini (1971), Fornaciari et al., (1996), Fornaciari \& Rio (1996), Raffi et al. (2003, 2006). Numerical ages of biozone boundaries are given according to Lourens et al. (2004), Raffi et al. (2006).

\section{Results and Discussion}

Preliminary biostratigraphic results for the Kotaphi Hill section are plotted in Figure 3 LO of Sphenolithus belemnos, LCO of Sphenolithus heteromorphus, PB of S. heteromorphus and LO Helicosphaera ampliaperta are some of calcareous nannofossils biohorizons that have been recorded in the Kotaphi Hill section. Semiquantitative results of the major representatives of calcareous nannofossils evaluated in the studied samples of the Kotaphi Hill section are presented in Table 1.

Table 1 - Species frequencies of calcareous nannofossils per sample of the Kotaphi Hill section as follows: A: abundant, $C$ : common, $R$ : rare, P: present, $\mathrm{RW}$ : reworked.

\begin{tabular}{|c|c|c|c|c|c|c|c|c|c|c|}
\hline $\begin{array}{c}\text { Sample/ } \\
\text { caclacreous } \\
\text { Nannofossil } \\
\text { species }\end{array}$ & 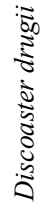 & 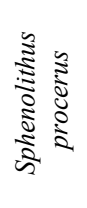 & 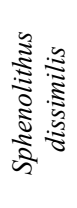 & 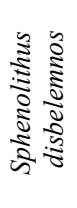 & 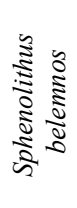 & 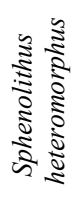 & 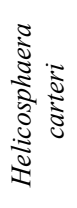 & 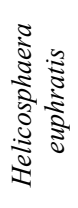 & 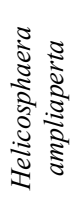 & 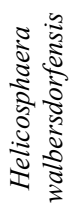 \\
\hline $\mathrm{K} \Delta 5$ & $\mathrm{~A}$ & $\mathrm{R}$ & $\mathrm{P}$ & & & & $\mathrm{C}$ & $\mathrm{C}$ & & \\
\hline $\mathrm{K} \Delta 10$ & A & $\mathrm{R}$ & $P$ & & & & $\mathrm{C}$ & $\mathrm{C}$ & & \\
\hline $\mathrm{K} \Delta 15$ & $\mathrm{C}$ & $\mathrm{P}$ & $\mathrm{R}$ & & & & $\mathrm{C}$ & $\mathrm{R}$ & & \\
\hline $\mathrm{K} \Delta 19$ & $\mathrm{C}$ & & $\mathrm{R}$ & & & & A & $\mathrm{R}$ & & \\
\hline $\mathrm{K} \Delta 21$ & $\mathrm{C}$ & & $\mathrm{R}$ & $\mathrm{P}$ & $\mathrm{R}$ & & A & $\mathrm{R}$ & $\mathrm{P}$ & \\
\hline $\mathrm{K} \Delta 25$ & $\mathrm{C}$ & & $\mathrm{P}$ & $\mathrm{P}$ & $\mathrm{R}$ & & A & $\mathrm{R}$ & $\mathrm{C}$ & \\
\hline $\mathrm{K} \Delta 27$ & $\mathrm{C}$ & & & $\mathrm{R}$ & $\mathrm{C}$ & $\mathrm{R}$ & A & $\mathrm{R}$ & $\mathrm{C}$ & \\
\hline $\mathrm{K} \Delta 31$ & $\mathrm{R}$ & & $P$ & $\mathrm{R}$ & $\mathrm{C}$ & $\mathrm{R}$ & A & $\mathrm{R}$ & $\mathrm{R}$ & \\
\hline $\mathrm{K} \Delta 35$ & $\mathrm{C}$ & & & $\mathrm{R}$ & $\mathrm{C}$ & $\mathrm{R}$ & A & $\mathrm{R}$ & $\mathrm{R}$ & \\
\hline $\mathrm{K} \Delta 40$ & $\mathrm{C}$ & & & $\mathrm{R}$ & $\mathrm{R}$ & $\mathrm{R}$ & A & $\mathrm{R}$ & & \\
\hline $\mathrm{K} \Delta 43$ & $\mathrm{C}$ & & & $\mathrm{P}$ & $\mathrm{R}$ & $\mathrm{R}$ & A & $\mathrm{R}$ & & \\
\hline $\mathrm{K} \Delta 45$ & $\mathrm{C}$ & & & $\mathrm{P}$ & $\mathrm{R}$ & $\mathrm{C}$ & A & $\mathrm{R}$ & & \\
\hline $\mathrm{K} \Delta 49$ & $\mathrm{C}$ & & & & RW & $\mathrm{C}$ & A & $\mathrm{R}$ & & \\
\hline $\mathrm{K} \Delta 53$ & $\mathrm{C}$ & & & & RW & $\mathrm{C}$ & A & $\mathrm{R}$ & & \\
\hline $\mathrm{K} \Delta 57$ & $\mathrm{C}$ & & & RW & RW & $\mathrm{C}$ & A & $\mathrm{R}$ & $\mathrm{P}$ & \\
\hline $\mathrm{K} \Delta 60$ & $\mathrm{R}$ & & & & RW & $\mathrm{C}$ & $\mathrm{C}$ & $\mathrm{C}$ & & \\
\hline $\mathrm{K} \Delta 62$ & $\mathrm{C}$ & & & & RW & $\mathrm{C}$ & $\mathrm{C}$ & $\mathrm{C}$ & & \\
\hline $\mathrm{K} \Delta 65$ & $\mathrm{C}$ & & & RW & RW & $\mathrm{C}$ & $\mathrm{C}$ & $\mathrm{C}$ & & $\mathrm{P}$ \\
\hline $\mathrm{K} \Delta 68$ & $\mathrm{C}$ & & & & RW & $\mathrm{C}$ & A & $\mathrm{C}$ & $\mathrm{P}$ & \\
\hline $\mathrm{K} \Delta 70$ & $\mathrm{C}$ & & & & & & A & $\mathrm{C}$ & $\mathrm{P}$ & \\
\hline $\mathrm{K} \Delta 73$ & $\mathrm{C}$ & & & & & $\mathrm{R}$ & A & $\mathrm{C}$ & $\mathrm{P}$ & $\mathrm{P}$ \\
\hline $\mathrm{K} \Delta 77$ & $\mathrm{C}$ & & & & & & A & $\mathrm{C}$ & & $\mathrm{P}$ \\
\hline $\mathrm{K} \Delta 80$ & $\mathrm{P}$ & & & & & & A & $\mathrm{P}$ & $\mathrm{P}$ & $\mathrm{P}$ \\
\hline $\mathrm{K} \Delta 82$ & $\mathrm{P}$ & & & & & & A & $\mathrm{P}$ & & $\mathrm{P}$ \\
\hline
\end{tabular}

\subsection{Biozone NN2 (MNN2)}

High abundance of D. druggii and low percentages of Discoaster deflandrei along with the HO of Sphenolithus procerus and continuous presence of Sphenolithus dissimilis in the first $4.9 \mathrm{~m}$ of the section, enable the biostratigraphic correlation with biozone NN2 (Martini, 1971). Based on the calcareous nannofossil analysis, the rare presence of $S$. procerus in the investigated assemblage is strengthening our biozonal determination. In the Mediterranean region, the HCO of Helicosphaera 


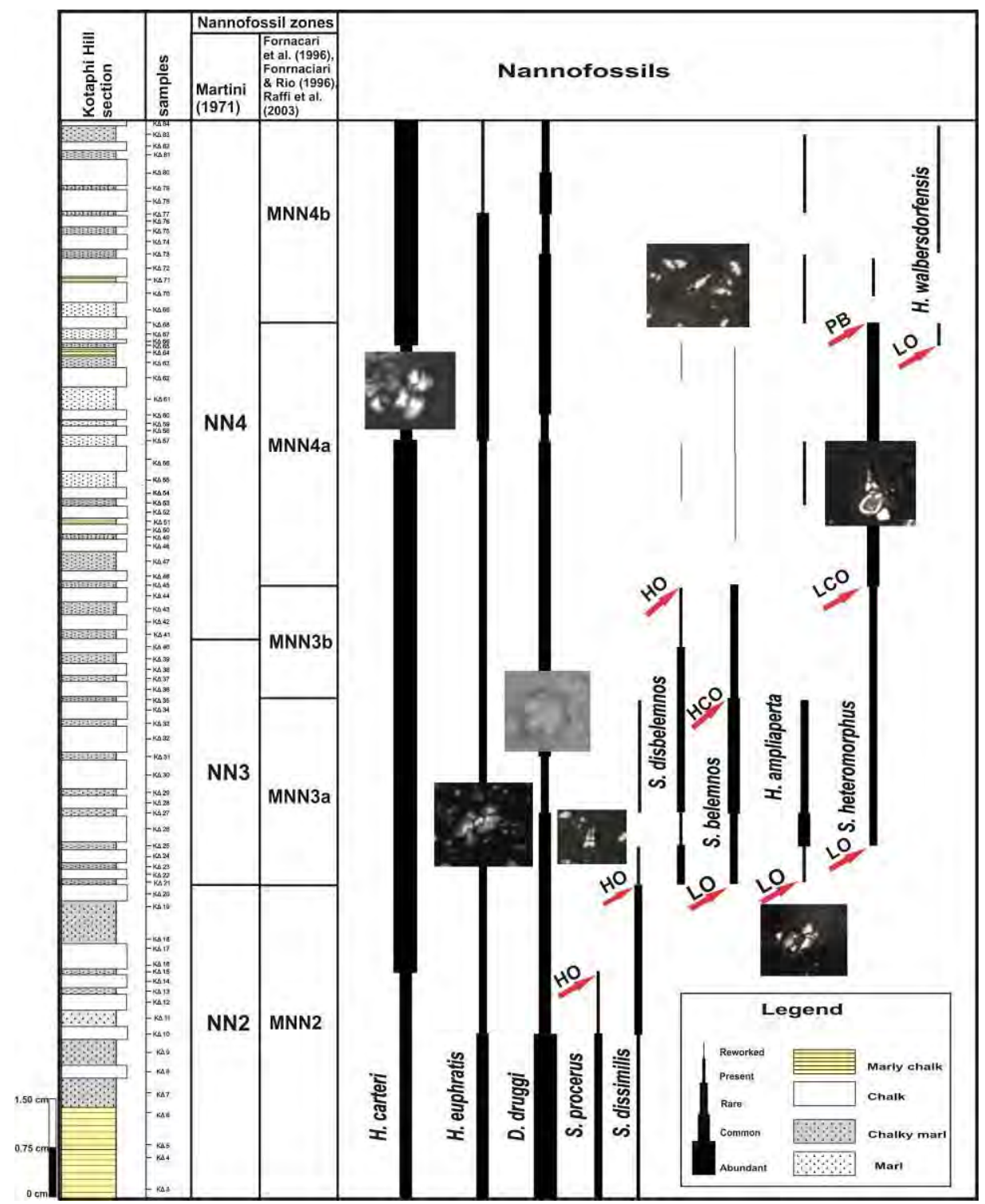

Figure 3 - Preliminary calcareous nannofossil biostratigraphy of Kotaphi Hill section.

euphratis has been correlated with the LCO of Helicosphaera carteri in the NN2 biozone (Coccioni et al., 1997). According to Fornaciari, \& Rio (1996), the dominance of $H$. carteri over $H$. euphratis is very distinctive in this interval. Our data document the dominance of $H$. carteri over $H$. euphratis, thus supporting the biostratigraphic recognition of biozone NN2. Minor components in our assemblages are also Sphenolithus compactus and Sphenolithus conicus, while the abundant presence of Sphenolithus moriformis is also noted.

\subsection{Biozone NN3 (MNN3)}

Although there are some contradictions in the literature concerning the presence of S. belemnos in the Mediterranean stratigraphic record, LO and HCO of this species is very often used to define NN3 zone. First rare representatives of S. belemnos together with the presence of Sphenolithus disbelemnos above the first $4.9 \mathrm{~m}$ of Kotaphi Hill section are used in this study to define the boundary between NN2/NN3. Despite the fact that generally, LO of $S$. disbelemnos is recorded 
slightly below the LO of $D$. druggii (Fornaciari, \& Rio, 1996), S. disbelemnos is totally absent within NN2 range in our section. According to Fornaciari \& Rio (1996) the absence of this species in NN2 biozone and its re-appearance at the lower part of NN3 seems to be a useful biostratigraphic evidence for this interval in the Mediterranean. In addition, Fornaciari \& Rio (1996) and Raffi et al. (2003), also mentioned that HCO of S. belemnos is used to define the boundary level between MNN3a/MNN3b. The transition of common to rare presence of $S$. belemnos along with the increased in abundance of $S$. heteromorphus over the $\sim 7.7 \mathrm{~m}$ of the section may reflect this boundary level in our material. Discoasters are characterised by abundant presence of $D$. deflandrei and common presence of $D$. druggii, while among sphenoliths,

S. moriformis seems to be the dominant species. Among helicoliths, the presence of $H$. ampliaperta is common whereas the abundant presence of $H$. carteri is the dominant feature of the assemblage.

\subsection{Biozone NN4 (MNN4)}

Martini (1971) defines the $\mathrm{HO}$ of $S$. belemnos and LO of S. heteromorphus as the marker events for the NN3/NN4 boundary. Co-occurrence of both species is reported by some authors (e.g., Bukry, 1972; Takayama \& Sato 1985) while others have indicated that the range of the two species cannot be considered to overlap (Olafsson 1989; Rio et al., 1990b). In the Mediterranean region, the intervals of high abundance of the two species do not overlap, but between the HCO of $S$. belemnos and the LCO of S. heteromorphus, the two forms may be present discontinuously and in low abundances (Olafsson, 1991; Fornaciari, \& Rio, 1996). Based on Marini (1971) biozonation, rare presence of $S$. belemnos after $8.5 \mathrm{~m}$ of Kotaphi Hill section along with the common presence of $S$. heteromorphus is likely to mark the NN3/NN4 boundary. Furthermore, Fornaciari \& Rio (1996) and Raffi et al. (2003), mentioned that in the Mediterranean region the boundary level of MNN3b/MNN4a is defined by the LCO of S. heteromorphus. The transition from rare to common presence of $S$. heteromorphus above $9.5 \mathrm{~m}$ of the section is possibly marking the LCO of the species and therefore the boundary level MNN3b/MNN4a in the studied material. Scattered and discontinuous presence of $S$. belemnos above the $9.5 \mathrm{~m}$ of the section may be due to enhanced reworking effect observed in our study material. Following Fornaciari et al. (1996), the lower boundary of the NN4 zone (MNN4a) is based on the LCO of S. heteromorphus, while the upper part of the zone (MNN4b) is characterized by the temporary absence (paracme beginning, $\mathrm{PB}$ ) of the species. In our study material, at about $13.5 \mathrm{~m}$ of the section, $S$. heteromorphus seems to be intensively reduced and rapidly disappeared afterwards, a pattern that continues upwards covering the last $3 \mathrm{~m}$ of the studied section. H. ampliaperta is common and continuously present at the lower part of NN4 (MNN4a) zone whereas at the upper part (MNN4b), its presence becomes discontinuous (Fornaciari et al., 1996). Such pattern of continuous presence of H. ampliaperta is not observed in the study area possibly due to regional and/or ecological criteria or other environmental factors that are still to be investigated. Similar distribution pattern with scattered and discontinuous presence or even absence of the species in the Mediterranean region within the NN4 zone was previously mentioned by other authors (Olafsson, 1991) and recently by Di Stefano (2011). Total assemblages from Kotaphi Hill contain abundant-common presence of $H$. carteri while $H$. intermedia, $H$. mediterranea and $H$. euphratis are also present. Among the sphenoliths, $S$. heteromorphus and $S$. moriformis are dominant mainly in the lower part of the interval. At the upper part of NN4 (MNN4b) the abundant presence of S. moriformis over S. heteromorphus and the total absence or very low abundance of the latter species represents a clear pattern. $D$. deflandrei is usually abundant dominating among discoasterids, while Discoaster exilis and Discoaster variabilis appear for the first time within this interval. The absence of $S$. heteromorphus together with the discontinuous presence of $H$. walbersdorfensis at the uppermost $3 \mathrm{~m}$ of the studied section, are likely to mark the PB of S. heteromorphus. This interval of virtual absence or reduced abundance ("paracme") of $S$. heteromorphus distribution range is well documented in several Langhian Mediterranean sections (e.g., Fornaciari et al. 1996; Di Stefano et 
al. 2008), representing a useful and reliable correlation tool within the Mediterranean Miocene sediments (Di Stefano, 2011).

\subsection{Biochronologic Assignment and Paleoceanographic Implications}

The calcareous nannofossil biostratigraphy applied at the studied samples recovered from the lower $16.50 \mathrm{~m}$ of Kotaphi Hill section, enabled biostratigraphic assignment of the studied deposits to NN2-NN4 (MNN2-MNN4) biozones. Therefore based on the astronomically calibrated data for the Neogene (Louerns et al., 2004: Raffi et al., 2006), the studied section possibly spans ca. 22.815.0 Ma, within the Aquitanian - Langhian time interval.

The Miocene Climate Optimum (MMCO) warm event occurred at about 15.0 Ma and represents one of the last warm periods of the Neogene. In general, Miocene is considered to be a time period of global climatic changes. More specifically, the Early and Middle Miocene were marked by a several million-year period of warm climate, which came to an end during the Middle Miocene global climate transition. The MMCO is traced by changes in the oxygen isotope values from the deep-sea sediment cores from ocean floor (e.g., Zachos et al., 2001), as well as by the marine and continental fossil record (e.g., Ivanov et al. 2002; Jiménez-Moreno, 2006). MMCO reached its maximum during 15.0-17.0 Ma (Zachos et al., 2001), within the standard nannoplankton zones NN4 and NN5.

The uppermost part of our study material (NN2-NN4) can be partly referred to the beginning of the MMCO, in particular the detected high abundances of discoasterids and sphenoliths support the prevalence of warm water conditions (e.g., Rio et al., 1990). In addition high abundance of helicoliths (particularly $H$. carteri) indicates warm surface waters with a medium to high content of nutrients (Negri \& Villa, 2000; Melinte, 2005).

\section{Conclusions}

Preliminary biostratigraphic results from Kotaphi Hill section indicated that several important calcareous nannofossil events can be traced along the studied section, including HO of $S$. procerus, and increased presence of $H$. carteri, suggesting that the lower $4.9 \mathrm{~m}$ of the section is probably correlated with NN2 (MNN2) biozone (Martini, 1971; Fornaciari \& Rio, 1996; Fornaciari et al., 1996, Raffi et al., 2003). The base of NN3 biozone is marked by the LOs of S. belemnos and $S$. disbelemnos, while the range of both species along with low abundances of $S$. heteromorphus are indicative of the NN3 (MNN3) biostratigraphic interval. Based on Fornaciari \& Rio (1996) and Raffi et al. (2003), the HCO of $S$. belemnos is the marker event for the MNN3a/MNN3b that is placed at $\sim 7.7 \mathrm{~m}$ of the studied section.

Moving upwards, the LCO of $S$. heteromorphus is used to define the MNN3b/ MNN4 located at the $9.5 \mathrm{~m}$ of the section. Biozone NN4 (MNN4) in Kotaphi Hill section is featured by abundant presence of well developed $S$. heteromorphus forms and increased presence of $D$. deflandrei, associated with the appearance of other forms of discoasterids such as D. exilis and D. variabilis. A pattern of almost total absence or low abundance of $S$. heteromorphus at $13.5 \mathrm{~m}$ from the base of the section and the dominance of $S$. moriformis together with the discontinuous presence of $H$. walbersdorfensis observed at the last $3 \mathrm{~m}$ of the section are the events marking the $S$. heteromorphus (PB) interval.

The preliminary calcareous nannofossil biostratigraphic results derived from the semiquantitative analysis of the studied samples recovered from the lower $16.50 \mathrm{~m}$ of Kotaphi Hill section, enabled the biostratigraphic assignment of the studied deposits to NN2-NN4 (MNN2-MNN4) biozones, spanning ca. 22.8-15.0 Ma, within the Aquitanian-Langhian time interval. High abundance of warm indicators such as discoasterids, $S$. heteromorphus, $S$. moriformis, and $H$. carteri may partly reflect the onset of the warm phase of MMCO global climatic event. On-going detailed quantitative analysis of nannofossil assemblages from the whole Kotaphi Hill section will provide further improvements to the proposed biostratigraphic and paleoceanographic assignments.

$\underline{\text { XLVII, No } 1-69}$ 


\section{Acknowledgments}

Funding was provided by the European Research Project EraNet/MarinERA, MedEcos and Research Project KA 70/4/11078 of the University of Athens. Thoughtful discussions with Emma Sheldon are greatly appreciated. Special thanks to Cyprus Geological Survey for all the support provided during the sampling of the section and to the two anonymous reviewers for providing constructive criticism.

\section{References}

Aubry M.P. 1984, 1988, 1989, 1990, 1999. Handbook of Cenozoic Calcareous Nannoplankton, Vol. 1-5, Micropress, American Museum of Natural History, New York.

Bukry D., 1972. Coccolith stratigraphy Leg 1, Init. Rep. DSDP 14, 487-494.

Coccioni R., Montanari A., Fornaciari E., Rio D. and Zevenboom D. 1997. Potential integrated stratigraphy of the Aquitanian to Upper Burdigalian section at Santa Croce di Arcevia (NE Apennines, Italy), in: Montanari, A., Odin, G.S., Coccioni, R., (Eds), Mioc. Stratigr. An Integrated Approach, pp. 275-295.

Di Stefano A., Foresi L.M., Lirer F., Iaccarino S.M., Turco E., Amore F.O., Mazzei R., Morabito S., Salvatorini G. and Abdul Aziz H. 2008. Calcareous plankton high resolution biomagnetostratigraphy for the Langhian of the Mediterranean area, Riv. Ital. Paleontol. Stratigr., 114(1), 51-76.

Di Stefano A., Verducci M., Cascella A. and Iaccarino S.M. 2011. Calcareous plankton events at the Early/MiddleMiocene transition of DSDP Hole 608: comparison with Mediterranean successions for the definition of the Langhian GSSP, Stratigr., 8, 89-110.

Follows E.J. and Robertson A.H.F., 1990. Sedimentology and structural setting of Miocene reefal limestones in Cyprus, in: Moores, E., et al., (Eds), Ophiolites and Oceanic Lithosphere, Proc. Int, Symp., Nicosia, Cyprus, Oct. 1987, pp. 207-215.

Fornaciari E. and Rio D. 1996. Latest Oligocene to early Middle Miocene quantitative Calcareous Nannofossil Biostratigraphy in the Mediterranean region, Micropaleont., 42 (1), 1-36.

Fornaciari E., Di Stefano A., Rio D. and Negri A., 1996. Middle Miocene quantitative calcareous nannofossil biostratigraphy in the Mediterranean region. Micropaleont., 42 (1), 37-63.

Hsü K.J., 1973. The desiccated deep basin model for the Messinian events, in: Drooger, C.W., (Ed.), Messinian Events in the Mediterranean, North-Holland, Amsterdam, pp. 60-70.

Hüsing S.K., Cascella A., Hilgen F.J., Krijgsman W., Kuiper K.F., Turco E. and Wilson D. 2010. Astrochronology of the Mediterranean Langhian between 15.29 and 14.17 Ma, Earth Planet. Sci. Lett., 290, 254-269.

Ivanov D., Ashraf A.R., Mosbrugger V. and Palamarev E. 2002. Palynological evidence for Miocene climate change in the Forecarpathian Basin (Central Paratethys, NW Bulgaria), Palaeogeogr., Palaeoclimatol., Palaeoecol., 178, 19-37.

Jiménez-Moreno G. 2006. Progressive substitution of a subtropical forest for a temperate one during the middle Miocene climate cooling in Central Europe according to palynological data from cores Tengelic-2 and Hidas-53 (Pannonian Basin, Hungary), Review of Palaeobot. and Palynol., 142, 1-14.

Lourens L., Hilgen F., Shackleton N.J., Laskar J. and Wilson J. 2004. The Neogene period, in: Gradstein, F.M., et al., (Eds), A Geologic Time Scale 2004, Cambridge University Press, pp. 409-440.

Martini E. 1971. Standard Tertiary and Quaternary calcareous nannoplankton zonation. In: Farinacci, A., (Ed.), Proceedings of the Second International Conference on Planktonic Microfossils, Roma, Rome, Ed. Tecnosci, vol. 2, pp. 739-785.

Melinte M.C. 2005. Oligocene palaeoenvironmental changes in the Romanian Carpathians, revealed by calcareous nannofossils, in: Tyszka, J., Oliwkiewicz-Miklasinska, M., Gedl, P., Kaminski, M.A., (Eds), Methods and Applications in Micropalaeont.. Studia Geologica Polonica, vol. 124, pp. 341-352. 
Negri A. and Villa G., 2000. Calcareous nannofossil biostratigraphy, biochronology and paleoecology at the Tortonian/Messinian boundary of the Faneromeni section (Crete), Palaeogeog. Palaeoclim., Palaeoecol., 156, 195-209.

Olafsson G. 1989. Quantitative calcareous nannofossil biostratigraphy of upper Oligocene to Middle Miocene sediment from ODP hole 667A and Middle Miocene sediments from DSDP Site 754, Proc. ODP Sci. Results, 108, 9-22.

Olafsson G. 1991. Quantitative calcareous nannofossil biostratigraphy and biochronology of early through late Miocene sediments from DSDP Hole 608, Medd. Stockholm Univ. Inst. Geol. Geok., 203 (4), 28 pp.

Perch-Nielsen K. 1985. Cenozoic calcareous nannofossils, in: Bolli, H.M., Saunders, J.B., PerchNielsen, K., (Eds), Plankt. Stratigr., Cambridge Earth Science Series, pp. 427-554.

Raffi I., Mozzato C.A., Fornaciari E., Hilgen F.J. and Rio D. 2003. Late Miocene calcareous nannofossil biostratigraphy and astrobiochronology for the Mediterranean region, Micropaleontol. 49, 1-26.

Raffi I., Backman J., Fornaciari E., Pälike H., Rio D., Lourens L. and Hilgen F. 2006. A review of calcareous nannofossil astrobiochronology encompassing the past 25 million years, Quarter. Scien. Rev., 25, 3113-3137

Rio D., Fornaciarı E. and Raffi I. 1990a. Late Oligocene through Early Pleistocene calcareous nannofossils from western equatorial Indian Ocean (Leg 115), Proceedings of the Ocean Drilling Program, Scientific Results, 115, 175-235.

Rio D., Raffi I. and Villa G. 1990b. Pliocene-Pleistocene calcareous nannofossil distribution patterns in the Western Mediterranean, Proc. ODP Sci. Results, 107, 513-533.

Robertson A.H.F. 1976. Pelagic chalks and calciturbidites from the Lower Tertiary of the Troodos Massif, Cyprus, J. Sediment. Petrol., 46, 1007-1016.

Robertson A.H.F., Eaton S., Follows E.J. and McCallum J.E. 1991. The role of local tectonics versus global sea-level change in the Neogene (Miocene-Pliocene) evolution of the Cyprus active margin. In: D.I.M. MacDonald (Editor), Sedimentation, Tectonics and Eustacy, Int. Assoc. Sedimentol., Spec. Publ., 12, 331-372.

Robinson P.T. and Malpas J. 1990. The Troodos ophiolite of Cyprus: new perspectives on its origin and emplacement, in: Malpas, J, (Ed.), Ophiolites-oceanic crust analogues, Proceedings of the Troodos 1987, Symposium, Nicosia, Cyprus Geological Survey, pp. 1326

Rouchy J.M., Orszag-Sperber F., Blanc-Valleron M-M., Pierre C., Rivière M., CombourieuNebout N. and Panayides I. 2001. Paleoenvironmental changes at the Messinian- Pliocene boundary in the Eastern Mediterranean (Southern Cyprus basins): significance of the Messinian Lago-Mare, Sedimentol. Geol., 145, 93-117.

Takayama T. and Sato T. 1985. Coccolith biostratigraphy of the North Atlantic Ocean, Deep Sea Drilling Project Leg 94, in: Ruddiman, W.F., Kidd, R.B., Thomas, E., et al., (Eds), Initial Reports of Deep Sea Drilling Project, vol. 94, pp. 651-702.

Zachos J.C., Pagani M., Sloan L., Thomas E. and Billups K. 2001. Trends, rhythms, and aberrations in global climate 65 Ma to present, Science, 292, 686-693. 